\title{
Lightning Related Deaths in Istanbul, Between 2007-2012
}

\section{İstanbul'da 2007-2012 Yılları Arasında Yıldııım Çarpmasına Bağlı Ölümler}

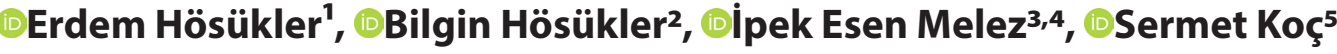 \\ 'Abant İzzet Baysal University, Faculty of Medicine, Department of Forensic Medicine, Bolu, Turkey \\ ${ }^{2} U$ şak University, Faculty of Medicine, Department of Forensic Medicine, Uşak, Turkey \\ ${ }^{3}$ Bezmialem Vakıf University, Faculty of Medicine, Department of Forensic Medicine, İstanbul, Turkey \\ 4The Ministry of Justice Council of Forensic Medicine, İstanbul, Turkey \\ ${ }^{5}$ Cerrahpaşa University, Faculty of Medicine, Department of Forensic Medicine, İstanbul, Turkey
}

\begin{abstract}
Objective: Lightning injuries can cause a variety of injuries including "integumentary system, cardiac system, central nervous system, eyes and ears", in which some of them may cause death. In this study, it was aimed to evaluate crime scene findings, autopsy findings and histopathological findings by presenting 9 cases that died due to lightning strike.

Material and Method: Nine cases (0.3\%) included this study were obtained from the screening of a total 24,755 cases that were performed autopsy at the Council of Forensic Medicine, Istanbul between 2007 - 2012. All cases' age, gender, crime scene, circumstances during the event, witness statement, skin lession, autopsy findings, histopathological findings were evaluated.
\end{abstract}

Results: Three (33.3\%) cases were female and six (66.7\%) cases were male, and the mean age was $39.66 \pm 13.36$ (min: 18, max: 56). Fatal lightning strike occurred between April and September, but mostly in May. At autopsy, an external examination was revealed an electrical exit wound in 4 cases, burn areas on the skin in five cases, a Lichtenberg figure on the skin in two cases, and a burn in the hair surface in four cases.

Conclusion: Nonspecific findings are frequently detected in autopsies performed due to lightning strikes. However, crime scene investigation and the testimony of the witness may be the crucial indicative evidence for forensic investigators in getting an accurate diagnosis in cases of suspected lightning strikes. In addition, examining the clothes worn by victims provides important clues in diagnosis.

Keywords: Lightning strike, death, autopsy, forensic medicine
Öz

Amaç:Yıldırım yaralanmaları, "örtü sistemi, kalp sistemi, merkezi sinir sistemi, gözler ve kulaklar" dahil olmak üzere bazıları ölüme neden olabilen çeşitli yaralanmalara neden olabilir. Bu çalışmada yıldırım çarpması sonucu ölen dokuz olgunun sunularak, olay yeri bulguları, otopsi bulguları ve histopatolojik bulguların değerlendirilmesi amaçlanmışıır.

Gereç ve Yöntem: Çalışmaya dahil edilen dokuz olgu $(\% 0,3)$ 2007 - 2012 yılları arasında İstanbul Adli Tıp Kurumu'nda otopsi yapılan toplam 24.755 olgunun dosyalarının retrospektif taranmasından elde edildi. Tüm olguların yaşı, cinsiyeti, olay yeri, olay sırasındaki koşullar, tanık ifadesi, deri lezyonları, otopsi bulguları, histopatolojik bulgular değerlendirildi.

Bulgular: Olguların üçü $(\% 33,3)$ kadın, altı $(\% 66,7)$ olgu erkekti ve ortalama yaş 39,66 13,36 (min: 18, maks: 56) idi. Ölümcül yıldırım düşmesi Nisan ve Eylül ayları arasında, ancak çoğunlukla Mayıs ayında meydana geldi. Otopside 4 vakada elektriksel çıkış yarası, beş vakada ciltte yanık alanları, iki vakada ciltte Lichtenberg figürü ve dört vakada saçta yanık tespit edildi.

Sonuç: Yıldırım düşmesi nedeniyle yapılan otopsilerde spesifik olmayan bulgular sıklıkla saptanmaktadır. Bununla birlikte olay yeri incelemesi ve tanık ifadeleri bu olgularda doğru tanı koymada adli araştırmacılar için önemli argümanlardır. Ayrıca kişinin giydiği kıyafetlerin incelenmesi de tanı koymada önemli ipuçları sağlayabilir.

Anahtar Kelimeler: Yıldıım çarpması, ölüm, otopsi, adli tıp

Corresponding (iletişim): Erdem Hösükler, Abant İzzet Baysal University, Faculty of Medicine, Department of Forensic Medicine, Bolu, Turkey E-mail (E-posta): erdemhsklr@hotmail.com

Received (Geliş Tarihi): 10.05.2021Ａccepted (Kabul Tarihi): 24.08.2021 


\section{INTRODUCTION}

Lightning, following a zigzag way as branches when goes downward, is the electrical potential discharge between the cloud and the earth. ${ }^{[1]}$ Lightning can emit more than 1 million volts of energy, thus more than 200,000 amperes of current may occur. ${ }^{[2]}$ The air surrounding the lightning can heat up to 25,000 to $30,000{ }^{\circ} \mathrm{C}$. However, it does not always cause serious injury, as lightning contact is very short $(2 \mathrm{msec}){ }^{[3]}$ Lightning-related worldwide mortality rate is estimated to be $0.2-1.7$ deaths/million people. ${ }^{[4]}$ The idea that lightning will only strike during a storm is a myth. In fact, the most risky interval that a fatal injury due to ligtning strike may occur is the interval preceding the storm. Moreover, as the ligtning can travel horizontally as far as 10 miles and more, it may ocur when the weather is still sunny. ${ }^{[5]}$ Another myth is that ligtning strike is always lethal. On the contrary, the literature shows that the mortality rate is $10-30 \%$ due to lightning strikes. ${ }^{[2,4,5]}$ The electric current in lightning strike is direct current (DC) and the amount of DC current transmitted due to lightning strike is far higher than that produced by alternative current $(A C){ }^{[4]}$ There are seven different ways in which lightning can interact with human body: "direct strike, side flash (splash), touch (contact) voltage, step voltage (ground strike, stride potential, ground current), subsequent stroke, connecting leaders and shock waves".[6] Lightning incidents may cause a variety of injuries including "integumentary system, cardiac system, central nervous system, eyes and ears", in which some of them may cause death. ${ }^{[4-8]}$ In this study, it was aimed to evaluate crime scene findings, autopsy findings and histopathological findings of cases that died due to lightning strike in İstanbul.

\section{MATERIAL AND METHOD}

The study was carried out with the permission of Bolu Abant Izzet Baysal University Clinical Researches Ethics Committee Approval Date: 17/10/2020, Decision No: 423. All procedures were carried out in accordance with the ethical rules and the principles of the Declaration of Helsinki.

In Istanbul, a population of more than 18 million, all forensic autopsies are performed in the Morgue Department of The Ministry of Justice Council of Forensic Medicine. All referred judicial cases undergo autopsy at the Morgue Department. In this study, the achive files of 24,755 autopsy cases between the dates $1^{\text {st }}$ January, 2007 and $31^{\text {st }}$ December, 2012 which had been referred to the İstanbul Morgue Department of The Ministry of Justice Council of Forensic Medicine for determining the cause of death were retrospectively analyzed and the cases that had defined been to be lightning related deaths were included in the study and reviewed in a detailed way. The demographical, judicial and clinical data of the cases included in the study were evaluated through the parameters of age, gender, crime scene, circumstances during the incident, witness statement, skin lession, autopsy findings and histopathological findings. SPSS 21.0 (Armonk,
NY) statistics program was used for data analysis of the study. Descriptive statistics were presented with frequency, percentage, mean (mean), standard deviation (SD), minimum $(\min )$, maximum (max) values.

\section{RESULTS}

Screening of a total 24,755 cases revealed nine cases $(0.3 \%)$ of lightning strike deaths. Three $(33.3 \%)$ cases were female and six (66.7\%)cases were male, and the mean age was 39.66 \pm 13.36 (min: 18, max: 56). It was determined that six $(66.7 \%)$ cases were engaged in farming in the field, two (22.2\%) cases had been having a picnic in the picnic area, and one (11.1\%) case had been hunting in the forest during the ligtning strike incident (Table 1). Three cases in the field were on the tractor in the event of lightning strike. In seven cases, it was found that there were witness who saw a lightning strike at the scene (Table 1). These fatal lightning strikes occured between April and September, but mostly in May (Table 1). At autopsy, an external examination was revealed an electrical entry-exit wound in four cases (Figure 1), burn areas on the skin in five cases (Figure 2), a Lichtenberg figure on the skin in two cases (Figure 3), and burn in the hair surface in four cases (Figure 4) (Table 2). At autopsy, As an internal examination was revealed nonspecific findings in all cases, including widespread subpleural petechial hemorrhage at the lungs in eight cases (Figure 5), subepicardial hemorrhage in two cases, petechial hemorrhage on the heart in two cases, lung parenchyma and visceral pleura tears in one case, focal subarachnoidal hemorrhage in one case (Table 3 ). In all cases, intraalveolar fresh bleeding was detected in histopathological examination of the lungs (Table 3). In five cases, cutaneous changes compatible with electrical flow and heat affect (intraepidermal - subepidarmal seperation, elongation in the basal layer in spinal cells in the epidermis, fusiform shape, diffuse homogenization in the collagenous fibers of the dermis) were detected on histopathological examination of the skin (Table 3 ).

Table 1. Personality and environmental features of victims who died due to lightning strikes.

\begin{tabular}{ccccccc} 
Case & Age & Gender & $\begin{array}{c}\text { Circumstance } \\
\text { During the } \\
\text { Event }\end{array}$ & Crime scene & Month & $\begin{array}{c}\text { Witness } \\
\text { Statement }\end{array}$ \\
\hline 1 & 48 & Woman & Farmer & Field & 8 & + \\
2 & 19 & Man & Farmer & Tractor trailer & 7 & + \\
3 & 45 & Woman & Farmer & Field & 4 & + \\
4 & 56 & Man & Farmer & Tractor & 6 & - \\
5 & 46 & Woman & Picnicker & Picnic area & 9 & + \\
6 & 45 & Man & Picnicker & Picnic area & 5 & + \\
7 & 33 & Man & Farmer & Field & 5 & - \\
8 & 18 & Man & Farmer & Tractor & 5 & + \\
9 & 47 & Man & Hunter & Woodland & 9 & + \\
\hline
\end{tabular}


Table 2. External findings at autopsy in victims who died due to lightning strikes.

\begin{tabular}{ccccc} 
Case & $\begin{array}{c}\text { Electric Entry } \\
\text { Exit Wound }\end{array}$ & $\begin{array}{c}\text { Electrical } \\
\text { Burn }\end{array}$ & $\begin{array}{c}\text { Lichtenberg } \\
\text { Figures }\end{array}$ & $\begin{array}{c}\text { Singed } \\
\text { Hairs }\end{array}$ \\
\hline 1 & - & - & - & - \\
2 & - & - & - & - \\
3 & - & - & + & - \\
4 & + & + & - & + \\
5 & - & + & - & + \\
6 & + & + & - & + \\
7 & + & + & - & - \\
8 & + & - & - & - \\
9 & - & + & + & + \\
\hline
\end{tabular}

Table 3. Autopsy and histopathological findings in victims who died due to lightning strikes.

\begin{tabular}{|c|c|c|c|c|}
\hline Case & $\begin{array}{l}\text { Autopsy } \\
\text { Findings }\end{array}$ & $\begin{array}{l}\text { Histopathological } \\
\text { Lung Sign }\end{array}$ & $\begin{array}{l}\text { Histopathological } \\
\text { Skin Sign }\end{array}$ & $\begin{array}{l}\text { Other } \\
\text { Findings }\end{array}$ \\
\hline 1 & + & + & - & - \\
\hline 2 & + & + & - & $\begin{array}{l}\text { Subepicardial } \\
\text { hemorrhage }\end{array}$ \\
\hline 3 & + & + & - & - \\
\hline 4 & + & + & + & $\begin{array}{l}\text { Subepicardial } \\
\text { hemorrhage }\end{array}$ \\
\hline 5 & + & + & + & - \\
\hline 6 & + & + & + & - \\
\hline 7 & + & + & + & $\begin{array}{c}\text { Petechial } \\
\text { bleeding in the } \\
\text { heart, Focal } \\
\text { subarachnoidal } \\
\text { hemorrhage in } \\
\text { the brain }\end{array}$ \\
\hline 8 & + & + & + & \\
\hline 9 & + & + & - & $\begin{array}{c}\text { Petechial } \\
\text { bleeding in the } \\
\text { heart }\end{array}$ \\
\hline $\begin{array}{l}\text { 'Intraal } \\
\text { (intrae, } \\
\text { epider }\end{array}$ & $\begin{array}{l}r \text { fresh } \\
\text { nal }-s \\
\text { siform }\end{array}$ & $\begin{array}{l}\text { ng, }{ }^{2} \text { Cutaneous chanc } \\
\text { darmal seperation, el } \\
\text { diffuse homogenizati }\end{array}$ & $\begin{array}{l}\text { compatible with electrical } \\
\text { gation in the basal layer in } \\
\text { in the collagenous fibers in } t\end{array}$ & $\begin{array}{l}\text { flow and heat affect } \\
\text { in spinal cells in the } \\
\text { the dermis) }\end{array}$ \\
\hline
\end{tabular}

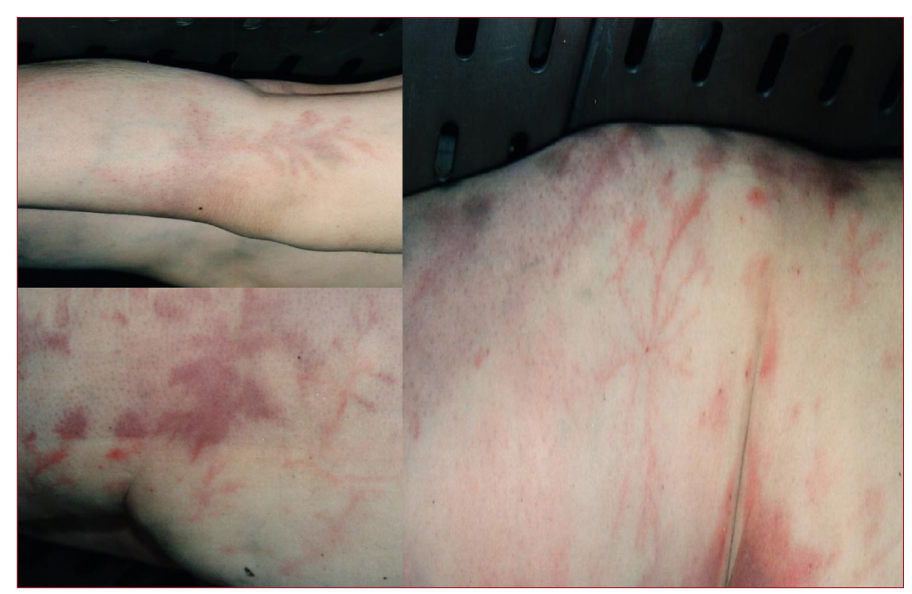

Figure 3. Lichtenberg figures on thighs, hips, and abdomen in Case 3.

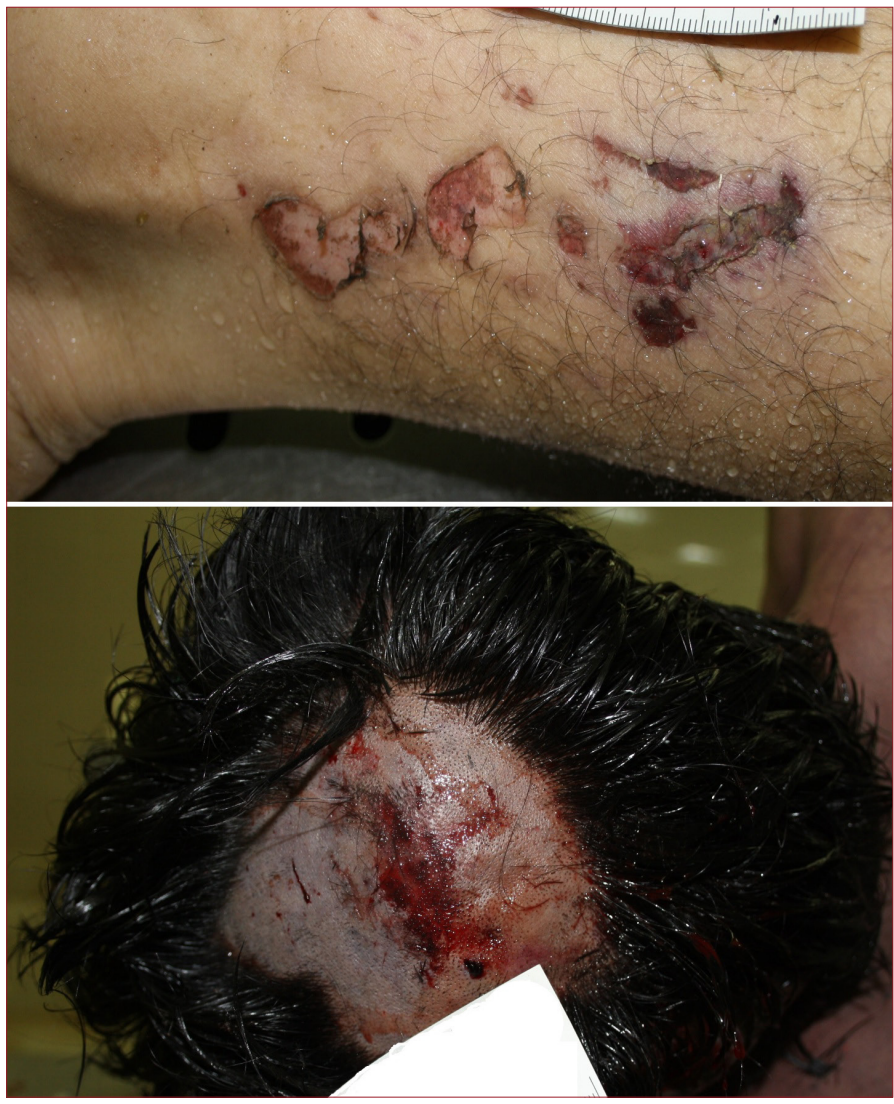

Figure 1. The electric entry wound on the scalp in the parietooccipital region and exit wound on the inner side of the right ankle in Case 7.

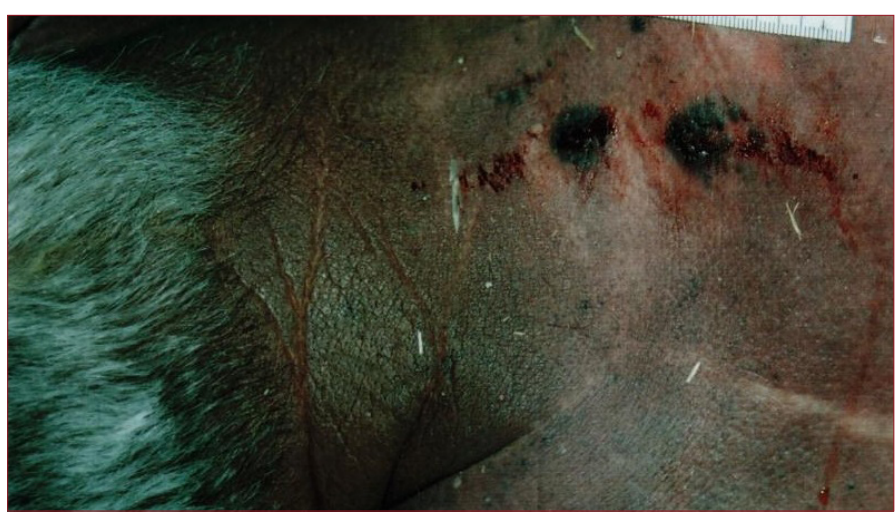

Figure 2. Point-shaped burn areas on the back in Case 5

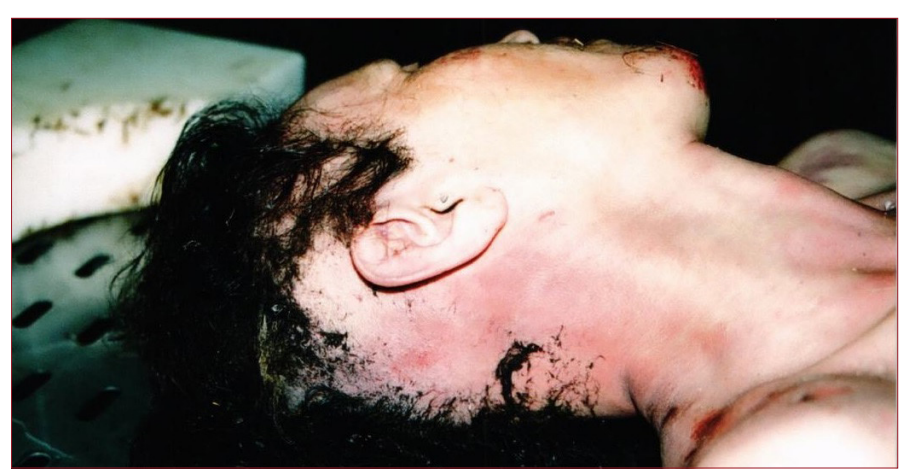

Figure 4. Burn in the hair surface in Case 6. 


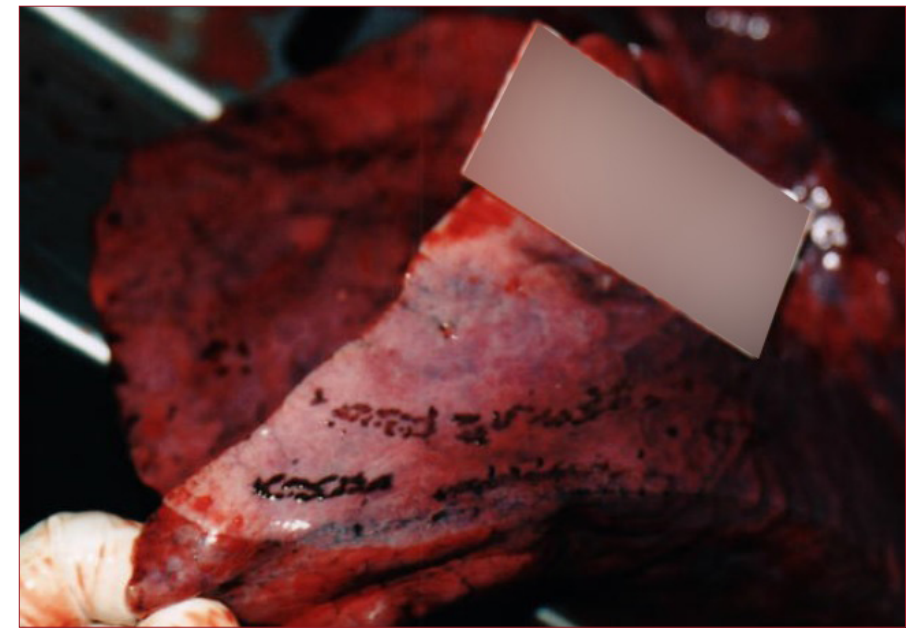

Figure 5. Linear subpleural petechial hemorrhages in the lung consistent with the passage of electric current

\section{DISCUSSION}

\section{General Knowledges of Lightning}

Approximately $10-30 \%$ of lightning injuries may result in death ${ }^{[4,5]}$ Seven different ways in which lightning can interact with human body are "direct strike, side flash (splash), touch (contact) voltage, step voltage (ground strike, stride potential, ground current), subsequent stroke, connecting leaders and shock waves".[6] Various injuries can occur through these mechanisms. Direct strike is generally seen in less than $5 \%$ of cases and is often fatal. ${ }^{[9]}$ Side flash (splash) injuries can be seen as a result of the lightning current jumps to a less resistant individual through a nearby object (the most common example; a tree) due to the potential differences. ${ }^{[5,10,11]}$ Touch (contact) injuries occur when the person is in contact with the object struck by lightning. ${ }^{[5,10]}$ Step voltage (stride voltage, ground current) injuries can be seen in cases where the lightning targets "the ground or any object in contact with the ground" near the person ${ }^{[5]}$ Here lightning current enters the body through one foot and leaves through the other. ${ }^{[10]} \mathrm{An}$ upward connecting leader is also explained as a current rising from the ground after a lightning strike, which struck the head or other upper body parts. ${ }^{[6]}$ Tympanic membrane perforation and blunt traumatic injuries can also be determined due to shock waves generated by lightning. ${ }^{[5,11]}$ Occasionally, after the first lightning near the person, the second strike can directly target the person, in which case the lightning can injure the person with both "step voltage" due to the first strike and with direct affect due to the subsequent one. ${ }^{[6]}$

\section{Gender}

The percentage of males that died due to lightning strikes in the United States between 2006 and 2016 was $91 \%{ }^{[12]}$ All of the cases exposed to the lightning strike presented by Nagesh et al were male and under the age of 35 (9). $55.5 \%$ of the cases exposed to lightning strikes within 10 years at a Swiss Trauma Center were reported to be male, and $44.5 \%$ female. ${ }^{[13]}$ In a study involving 47 cases died by lightning strike, $70.2 \%$ of the cases were male. ${ }^{[14]}$ Likewise, $79 \%$ of the deaths due to lightning strikes in South Africa were male. ${ }^{[15]}$ In a study conducted in the east of Turkey, $90.1 \%(1 / 11)$ of the cases died due to lightning strikes were reported to be male. ${ }^{[16]}$ In addition, it was stated that $87.5 \%$ of the cases in Eskisehir were male. ${ }^{[17]}$ In the present study, three (33.3\%) cases were female and six (66.7\%) cases were male.

\section{Age}

In the study of 47 cases died as a result of lightning strike, 33 of the cases were reported to be in 11-30 age range. ${ }^{[14]}$ In South Africa, the average age of the cases that died due to lightning strikes was $36 .^{[15]}$ In another study involving 54 cases in New Mexico, the mean age was reported to be $34 .{ }^{[18]}$ In the study of Hekimoglu and et al., the average age of cases died due to lightning strike was 23.5. ${ }^{[16]}$ The mean age of the cases in the present study was $39.66 \pm 13.36$ ( $\min : 18$, max: 56$)$.

\section{Scene}

In the United States, approximately two-thirds of deaths due to lightning strikes between 2006 and 2016 occurred during outdoor leisure activities (fishing, camping, beach, boat tour etc.). ${ }^{[12]}$ In a study conducted in New Mexico was reported that $27.8 \%$ of cases died a result of lightning strikes while working in a job ( working in the field, grazing sheep, etc.), and a larger part (72.2\%) in non-working activities (sport outdoors, fishing, camping, boating, etc.). ${ }^{[18]}$ In the study of 47 cases died by lightning strike, $48.9 \%$ of the cases were reported to be farmers. ${ }^{[14]}$ In the study of Hekimoglu et al., was reported that $36.4 \%$ of cases were soldier and $36.4 \%$ were farmer. ${ }^{[16]}$ In the present study, during the event, it was determined that six $(66.7 \%)$ cases were engaged in farming in the field, two (22.2\%) cases had been having a picnic, and one $(11.1 \%)$ case had been hunting in the forest.

It has been shown that close proximity to metal objects such as bicycles, trains and motor vehicles during a lightning incidents ${ }^{[18]}$ It is claimed that approximately $10 \%$ of lightning strikes are related to motor vehicles. ${ }^{[13]}$ The most likely places exposed to lightning strikes in car are "antenna, windshield and bonnet".[19] Pfortmueller et al. reported that two out of nine cases injured by lightning while driving. ${ }^{[13]}$ Three cases we presented were on the tractor in a field when the lightning strike.

\section{Session}

Lightning strikes have been reported to occur frequently in wet seasons in Malawi. ${ }^{[20]}$ Gadge and Shrigiriwar reported that deaths due to lightning strikes occured mostly in June, July and August. ${ }^{[14]}$ In New Mexico, $63 \%$ of 54 cases died as a result of lightning strikes were attacked in the summer. ${ }^{[18]}$ In the study of Hekimoglu et al., five cases (45.5\%) died in the summer and five cases died in the autumn. ${ }^{[16]}$ In the study of Turan et al., all deaths were in summer. ${ }^{[21]}$ In the present study, fatal lightning strike incidents were between April and September, but mostly in May. 


\section{Witness Testimony}

In cases found death due to lightning strikes, the testimony of the witness is one of the most important proofs that facilitates the decision in medicolegal investigations. In some studies conducted in Turkey, all cases have the testimony of the witness. ${ }^{[16,21]}$ In the present study, there was a witness who had saw a lightning strike at the scene in seven of nine cases. Moreover, although there was no external examination finding in the first and second cases, it was determined by the testimony of the witness that death due to a lightning strike occurred.

\section{Skin Lesions}

Linear burns, spot burns, singed hair, thermal burns and their combination can be seen due to lightning strikes. ${ }^{[4,5]} \mathrm{It}$ is estimated that linear burns between 1 and $4 \mathrm{~cm}$ in diameter are caused by evaporation of sweat due to thermal overloading on body surface. Linear burns, usually seen as first or second degree burn; often detected on the chest, armpit and under the breast. ${ }^{[4,5]}$ Multiple and closely spaced full layer spot burns, usually smaller than $1 \mathrm{~cm}$, can be seen on the tiptoes and edges of the plantar surface, as the "tip toe sign".[4,22] In singed hair findings, epidermis and dermis layers are often normal, but there is a singed appearance on the body surface hair. ${ }^{[4]}$ Thermal burns occur due to overheating of metal objects such as necklaces and bracelets by the lightning ${ }^{[4,23]}$ At postmortem cases, "skin burns, signed hair, torn clothes, melting of metal objects worn on the body such as belt buckles - jacket zipper - necklace, burnt cigarette box in the pocket" can be considered in diagnosis. ${ }^{[10,18]}$ In addition, lightning - related entry and exit lesions can also be seen on the skin. ${ }^{[24]}$ Pfortmueller et al. reported three of nine cases were injured as a result of lightning strike had skin findings, one of those three cases had mild skin lesions, while the other two had entry and exit lesions together with second and third degree burn areas. ${ }^{[13]}$ In the study involving 47 cases died by lightning strike, burns on the skin in $80.8 \%$ of the cases and singed hair in $42.5 \%$ of the cases were detected. ${ }^{[14]}$ In the autopsy study of lightning strikes in South Africa, thermal burns in $89.5 \%$ of cases ( $28 \%$ first degree, $73 \%$ second degree, $47 \%$ third degree), singed hair in $68 \%$ of cases and tears in clothes in $26 \%$ of cases were determined. ${ }^{[15]}$ In New Mexico study, it was shown that 16 cases had an entrance wound and 20 cases had an exit wound. ${ }^{[18]}$ In the study of Hekimoglu et al. linear burns in six cases $(54.5 \%)$, punctate burns in four cases $(36.4 \%)$, burns due to melting metal object in three cases $(27.3 \%)$, thermal burns in two cases $(18.2 \%)$ and burns due to the direct effect of lightning in three cases (27.3\%) have been found. ${ }^{[16]}$ Turan et al. showed that $71 \%$ singed hair, $63 \%$ traumatic lesions, $57 \%$ thermal burns and $14 \%$ electrothermal lesions were observed in seven cases died as a result of lightning strikes. ${ }^{[21]}$ In another study, $85.7 \%$ of the cases (6/7) had skin burns of varying degrees and $42.8 \%$ of cases (3/7) had electrical entry and exit lesions. ${ }^{[17]}$ In the present study at autopsy, an external examination was revealed an electrical entryexit wound in four cases (Figure 1), burn areas of varying degrees on the skin in five cases (Figure 2), and burn in the hair surface in four cases (Figure 4) (Table 2). Also, in five cases, cutaneous changes compatible with electrical flow and heat affect (intraepidermal - subepidarmal seperation, elongation in the basal layer in spinal cells of the epidermis, fusiform shape, diffuse homogenization in the collagenous fibers of the dermis) were detected on histopathological examination of the skin.

"Lichtenberg figures" are considered pathognomonic for lightning strikes, but they often develop in the first hours after the lightning strike and disappear within 24 hours. ${ }^{[2]}$ Also, it is rarely detected in autopsy in postmortem cases. [15] It is estimated that "Lichtenberg figures" may occur due to erythrocyte flow to the superficial skin layer in capillaries through the electrical deterioration and electric flux density on the skin. ${ }^{[25]}$ Blumenthal reported that none of the 38 cases who died due to lightning strike had a lichtenberg figure at autopsy. ${ }^{[15]}$ In New Mexico study, only $11.1 \%$ (6/54) of the cases were reported to have "Lichtenberg figure".[18] In the postmortem studies from Turkey, "Lichtenberg figures" were observed in between $29 \%$ and $63.6 \%$ of the cases died due to lightning strikes ${ }^{[16,17,21]}$ while in the present study it is observed in two cases (\%22.2) (Figure 3).

\section{Cardiac effects}

Among the proposed mechanisms for the effects of lightning strike on the heart; there are "induction of coronary artery spasm, catecholamine storm, direct thermal damage, ischemia secondary to arrhythmia and coronary artery ischemia due to widespread vascular damage".[26] A strong continuous contraction develops due to the simultaneous depolarization of the whole myocardium. ${ }^{[27]}$ The most common cause of death due to lightning strike is asystolic cardiac arrest or ventricular fibrillation. ${ }^{[4]}$ For ventricular fibrillation, lightning must occur just in time at the peak of the T wave, so asystole is predicted to be more frequent than ventricular fibrillation. ${ }^{[28]}$ However, secondary cardiac arrest may also develop as a result of deep hypoxia due to paralysis of respiratory muscles or inhibition of respiratory centers. ${ }^{[4,5]}$ "Ventricular fibrillation, asystole, hypertension, tachycardia, nonspecific ST and T wave changes, prolonged QT interval, premature ventricular contractions" can be seen due to lightning strikes. ${ }^{[5]}$ In addition, severe stunned myocardium and acute myocardial infarction can rarely be seen due to lightning strikes. ${ }^{[3,8]}$ Postmortem macroscopic heart alterations due to lightning strike are fairly seldom. ${ }^{[18]}$ Soft tissue bleeding in front of pericardium at autopsy was reported in only one $(4.7 \%)$ of 21 cases died due to lightning strikes in New Mexico. ${ }^{[18]}$ In the present study, macroscopic cardiac damage was observed as subepicardial hemorrhage in two cases(22.2\%) and petechial bleeding in two cases (22.2\%). 


\section{Lungs Effects}

Petechial hemorrhages can be seen on the pleural and epicardial surfaces as postmortem findings due to lightning strike. ${ }^{[29]}$ In addition, macroscopically intense pulmonary edema and congestion, histopathologically intense pulmonary edema and hemorrhage can also be seen. ${ }^{[29,30]}$ Burns in the chest area, lung and heart contusions can be occured especially such as necklaces worn on the chest area. [23] Aspiration bronchopneumonia, diffuse alveolar damage and pulmonary edema were detected at autopsy in 6 of 21 cases $(28.5 \%)$ died due to lightning strikes. ${ }^{[18]}$ Akkaya et al. detected lung contusion in $85.7 \%(6 / 7)$ of the autopsy cases. ${ }^{[17]}$ In two of the three cases presented by Dogan et al, detected lung contusion findings. ${ }^{[31]}$ Eight out of nine cases we presented had widespread subpleural petechial hemorrhage (Figure 5) and lung parenchyma and visceral pleura tears in one case. Also, in all cases, intraalveolar fresh bleeding was detected in histopathological examination of the lungs.

\section{Brain Effects}

It's important to discuss also the nervous system injuries due to the lightning strikes. Keroneuroparalysis is a transient condition due to lightning strikes in survivors characterized by limb paralysis, sensory paralysis, pulseless, pallor or cyanosis, motor or sensory loss. ${ }^{[32]}$ The nervous system, has been reported the most commond injury area due to lightning strikes in Switzerland. ${ }^{[13]}$ Epidural and subdural hemorrhage, respiratory center paralysis, intraventricular hemorrhage, petechiae and dural tears may be seen due to lightning current. ${ }^{[5]}$ Bone fractures, brain hemorrhage and internal organ injuries can be revealed as a result of burst effect of lightning. ${ }^{[2,33]}$ Bilateral or unilateral basal ganglia bleeding due to lightning strikes may also be seen. ${ }^{[7,34]}$ In the postmortem study of Pincus et al, was reported cerebral edema, subarachnoid, subgaleal and periosteal hemorrhage may be seen due to lightning strikes. ${ }^{[18]}$ In the study of Hekimoglu et al., craniocerebral trauma findings were detected in two of the victims. ${ }^{[16]}$ Likewise, Akkaya et al. detected contusion in the barin in three of the autopsy cases. ${ }^{[17]}$ In the present study, brain damage was observed as subarachnoid hemorrhage in only one out of nine cases.

\section{CONCLUSION}

As a result, nonspecific findings are frequently detected in autopsies performed due to lightning strikes. However, crime scene investigation and the testimony of the witness may be the crucial indicative evidence for forensic investigators in getting an accurate diagnosis in cases of suspected lightning strikes cases. In addition, examining the clothes worn by victims provides important clues in differential diagnosis.

\section{ETHICAL DECLARATIONS}

Ethics Committee Approval: The study was carried out with the permission of Bolu Abant Izzet Baysal University Clinical Researches Ethics Committee Approval Date: 17/10/2020, Decision No: 423.

Informed Consent: Because the study was designed retrospectively, no written informed consent form was obtained from patients.

Referee Evaluation Process: Externally peer-reviewed.

Conflict of Interest Statement: The authors have no conflicts of interest to declare.

Financial Disclosure: The authors declared that this study has received no financial support.

Author Contributions: All of the authors declare that they have all participated in the design, execution, and analysis of the paper, and that they have approved the final version.

Note: The study was presented as a poster presentation at the $14^{\text {th }}$ Forensic Science Congress held in İzmir - Turkey, between 11-14 May 2017.

\section{REFERENCES}

1. Butun C, Beyaztas FY, Yılmaz R. Lightning-related death. Turk Arch Ped 2012;47:63-6.

2. Figgis $P$, Alvarez $G$. Delayed esophageal perforation following lightning strike:a case report and review of the literature. J Med Case Reports 2012;6:244.

3. Riviera J, Romero KA, Gonzalez-Chon O, Uruchurtu E, Marquez MF Guevara M. Severe stunned myocardium after lightning strike. Crit Care Med 2007;35(1):280-5.

4. Ritenour AE, Morton MJ, McManus JG, Barillo DJ, Cancio LC. Lightning injury: a review. Burns 2008;34(5):585-94.

5. Gatewood MO, Zane RD. Lightning injuries. Emerg Med Clin N Am 2004;22(3):369-403.

6. Cooray V, Cooray C, Andrews CJ. Lightning caused injuries in humans. J Electrostatics 2007;65(5-6):386-94.

7. Lakshminarayanan S, Chokroverty S, Eshkar N, Grewal R. The spianl cord in lightning injury:a report of two cases. J Neurol Sci 2009;276(1-2):199201.

8. Saglam H, Yavuz Y, Yurumez Y, Ozkececi G, Kilit C. A case of acute myocardial infarction due to indirect lightning strike. J Electrocardiol 2007;40(6):527-30.

9. Nagesh IV, Bhatia P, Mohan S, Lamba NS, Sen S. A bolt from the blue: Lightning injuries. Med J Armed Forces India. 2015;71(Suppl 1):S134-7.

10. Zack F, Rotschild MA, Wegener R. Ligntning strike-mechanisms of energy transfer, cause of death, types of injury. Dtsch Arztebl 2007;104(5152):A3545-9.

11. Myung NS, Lee IW, Goh EK, Kong SK. Cochlear implantation for severe sensorineural hearing loss caused by lightning. Am J Otolaryngol. 2012;33(6):767-9.

12. Jensenius JS. A detailed analysis of recent lightning deaths in the United States. Fifth International Lightning Meteorology Conference, Tucson, USA. Vol. 2021. 2014.

13. Pfortmueller CA, Yikun $Y$, Haberkern $M$, Wuest $E$, Zimmermann $H$ Exadaktylos AK. Injuries, sequelae, and treatment of lightning-induced injuries:10 years of experience at a Swiss Trauma Center. Emerg Med Int. 2012;2012:167698.

14. Gadge, SJ, Shrigiriwar MB. Lightning:a 15 year study of fatal cases at SVNGMC Yavatmal. J. Forensic Med. Sci. Law 2013;22(1):1-5. 
15. Blumenthal R. Lightning fatalities on the South African Highveld:a retrospective descriptive study for the period 1997 to 2000. Am J Forensic Med Pathol. 2005;26(1):66-9.

16. Hekimoglu Y, Asirdizer M, Demir U, et al. An Autopsy Series: LightningRelated Deaths in Van and Hakkari Provinces. West Indian Med J. 2017.

17. Akkaya H, Karbeyaz K, Kokcuoglu MA, Urazel B. Llghtning Associated Deaths During 1997 - 2011 In Eskisehir. J For Med 2013;27(2):94-9.

18. Pincus JL, Lathrop SL, Briones AJ, Andrews SW, Aurelius MB. Lightning deaths:a retrospective review of New Mexico's cases, 1977-2009. J Forensic Sci. 2015;60(1):66-71.

19. Yanagawa S, Yamanoto K, Naito Y, Takahashi N, Matsui M. Investigations of lightning accidents on automobiles Electr Power Syst Res. 2016;139:2-9.

20. Mulder MB, Msalu L, Caro T, Salerno J. Remarkable rates of lightning strike mortality in Malawi. PLoS One. 2012;7(1):e29281.

21. Turan N, Birincioglu I, Butun C, Muhammet C. Findings in fatal lightning strike cases. Turkiye Klinikleri J Foren Med 2011;8(2):59-65.

22. Davis C, Engeln A, Johnson EL, McIntosh SE, et al. Wilderness Medical Society practice guidelines for the prevention and treatment of lightning injuries:2014 update. Wilderness Env Med. 2014;25(4 Suppl):S86-95.

23. Wankhede AG, Agrawal VR, Sariya DR. An injury subjacent to lac ornament in a case of lightning. Forensic Sci Int. 2010 25;195(1-3):e9-12.

24. Murty OP. Dramatic lightning injury with exit wound. J Forensic Leg Med. 2007;14(4):225-7.

25. Ocak T, Duran A, Tekelioglu UY, Demirhan A, Bekdaş M, Cetin A. Two cases of lightning strikes resulting in Lichtenberg figures. Dermatologica Sinica 2014;32(1):37-8.

26. McIntyre WF, Simpson CS, Redfearn DP, Abdollah H, Baranchuk A. The lightning heart:a case report and brief review of the cardiovascular complications of lightning injury. Indian Pacing Electrophysiol J. 2010;10(9):429-34.

27. Nelson KL, Mills $W$ Jr, Umbel S, Crosson JE, Shaffner DH, Hunt EA. Lightning, sudden cardiac death, simulation and an automated external defibrillator:the perfect storm. Resuscitation. 2007;74(3):567-71.

28. Levy DR, Akiyama T. Lightning-induced ventricular fibrillation. Cardiol J. 2007;14(1):91-4.

29. Wankhede AG, Sariya DR. Damage due to lightning when it strikes the face. Forensic Sci Int. 2013 10;224(1-3):e1-3.

30. Ventura F, Barranco R, Bonsignore A, De Stefano F. A Unusual lightning death in an indoor setting:a case report. Am J Forensic Med Pathol. 2017;38(1):1-4.

31. Dogan KH, Demirci S, Günaydın G. Deaths caused by lightning strike:case report of three cases. Genel Tıp Derg 2007;17(4):217-22.

32. Rahmani SH, Faridaalaee G, Jahangard S. Acute transient hemiparesis induced by lightning strike. Am J Emerg Med. 2015;33(7):984.e1-3.

33. Lizano-Díez X, Alentorn-Geli E, León-García A, Marqués-López F. Fracture of the femoral component after a lightning strike injury:a case report. Acta Orthop Traumatol Turc. 2017;51(1):84-7.

34. Ozgun B, Castillo M. Basal Ganglia Hemorrhage Related to Lightning Strike. AJNR Am J Neuroradiol. 1995;16(6):1370-1. 